\title{
研究論文
}

\section{8. 核爆発による放射性塵の測定および分析}

\author{
五十嵐 俊 次* \\ (1968年 9 月 27 日 受 理) \\ (1969年 3 月 7 .日 再受理)

\begin{abstract}
Measurements and Analyses of Radioactive Airborne Debris
from the Nuclear Test Explosion
\end{abstract}

By Shunji IGARASHI

\begin{abstract}
The radioactive airborne debris that reached the sky over Japan in the wake of the 7th Chinese nuclear test explosion of December 24, 1967 were collected with the use of an airborne dust sampler mounted on aircraft and subjected to gross $\beta$-activity measurement, $\gamma$-ray spectrometry and mass spectrometry. The concentration of radioactive debris in the air stood at about $18,000 \mathrm{pCi} / \mathrm{m}^{3}$ on December 25 , from where it decreased gradually to reach a level below $1 \mathrm{pCi} / \mathrm{m}^{3}$ on December 28 , the level prevalent before the test explosion. Short-lived radionuclides such as ${ }^{239} \mathrm{~Np},{ }^{143} \mathrm{Ce},{ }^{132} /$ and ${ }^{99} \mathrm{Mo}$ were clearly detected by $\gamma$-ray spectrometry, but the presence of ${ }^{237} \mathrm{U}$ was not confirmed. The elementary composition of the debris collected shortly after the explosion was not substantially different from those collected at normal times. The content of lithium however, was about 120 times as high as the level before the test explosion. The isotopic abundance ratio of ${ }^{6} \mathrm{Li}$ was $14.6 \%$, about twice the natural isotopic abundance ratio.
\end{abstract}

\section{I . 緒 言}

核爆発によって生ずる放射性塵中の核分裂生成物に 関してはすで多くの研究者によって究明されてお り,特に著量の ${ }^{237} \mathrm{U}$ 等の検出 ${ }^{(1)}$ は土注目されている。

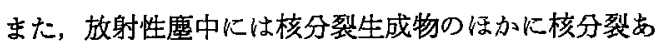
るいは核融合の材料物質の一部分が末反応のまま混っ ていることが知られて括り，この未反応物質の検出 ${ }^{(2)}$ は核爆発生成物を明らか比するのと考えられてい $3^{(3)}$ 。

1967年12月 24日に行われた中国の第 7 回目の核爆発 実験の際に，日本の上空に飛来した放射性塺を航空機 を用いて探取し，放射能の測定括よび含有核種の分析 を行うと共に，特に $\mathrm{Li}$ 含有率およびその同位体比の 測定に着目して，質量分析器により塺の組成元素を分 析し，平常に括ける放射性塵の組成と比較してその相
異を調ヘ，末反応物質の検出を試みた。

\section{II. 実 験 方法}

1. 試料の採集および処理

平常時に招いては，Fig. 1 に示す実線ループ内の 空域を $6 \mathrm{~km}, 10 \mathrm{~km}$ 打よび $12 \mathrm{~km}$ の 3 高度につい て週 1 回の予定で武料採集を行なっているが，1967年 12月24日に中国新疆省ロプノール地区 $\left(\mathrm{N}: 40^{\circ}, \mathrm{E}\right.$ : $90^{\circ}$ 付近) で行われた第 7 回核爆発実験に際しては, 次のようにして麿の採集を行なった。実験の当時，実 験場付近を通り九州，四国括よび紀伊半島をかすめて 約 $9 \mathrm{~km}$ の高度を毎時約 $180 \mathrm{~km}$ の速度て吹いてい たジット気流が出り，もしこの気流に新しい放射性 痤が乗って来るとすれば， $24 \mathrm{hr}$ 程度で日本上空侄到

* 防衛庁技術研究本部 第 1 研究所(The 1st Res. Center Tech. Res. \& Development Inst., J.D.A.) 


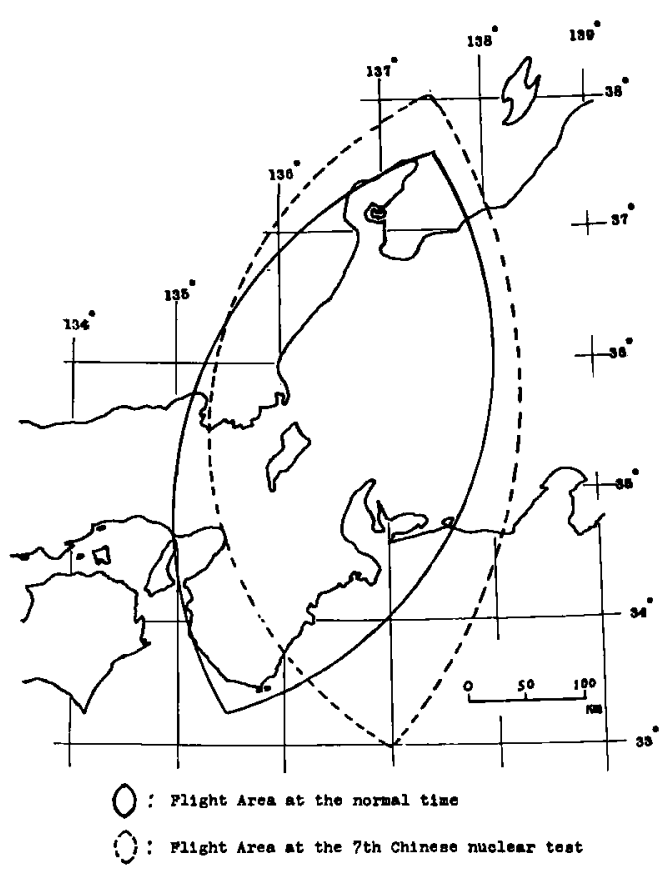

Fig. 1 Sampling area for radioactive airborne dusts at high altitude

達するものと予想された。また 5〜6 km の高度の気 流に乗った場合には，ジェット気流のコースよりるか なり北側圶通り到達時間も 40〜 $50 \mathrm{hr}$ を要するるのと 予想された。しかし今回は核爆発の正確な時刻および 高度等が明らかでなく，また確認する資料も得られな かったため，日本上空に塺の到達する時刻等について の予想ができなかったので，25日10時よりまずジェッ ト気流の通過予想コースである太平洋側 (Fig. 1 の点 線ループ内の南側半鸟）の空域を主に，また26日は 5 $\sim 6 \mathrm{~km}$ の高度の気流の予想コースにあたる日本海側 (Fig. 1 の点線ループ内の北側半分)の空域を主に， 全般的には平常時の飛行域を南北に拡げた状態で， 約 $2 \mathrm{hr}$ 間隔て 1 日 3 回程度, $6 \sim 10 \mathrm{~km}$ の高度を集塵 飛行して試料の採取を行なった。

平常時の採集は， $6 \mathrm{~km}$ および $10 \mathrm{~km}$ の 2 高度に ついては航空機(F-86F 型シェット機)の翼下面に装 着した沪紙式集麼器 ${ }^{(4)}$ を主として使用し， $12 \mathrm{~km}$ の高 度については翼前縁に添付したガムドペーパーを用い て行なっている。核爆発後の25日からの操集について もこれと同様にして行なった。

採集した試料は清浄な白金ルツボに入れ，開放型電 気师で約 $2 \mathrm{hr}, 400^{\circ} \sim 500^{\circ} \mathrm{C}$ に加熱して炭化した後， 電気マッフル师で約 $12 \mathrm{hr}, 600^{\circ} \mathrm{C}$ に熱して死化した。
灰化恒量後和量して兏の重量を求めた後ステンレス鋼 製の試料皿に移し，蒸留水を滴下して試料を武料皿の 底面に一様に拡げ，赤外楾ランプで乾固して放射能の 测定靖料とした。

2. 全 $\boldsymbol{\beta}$ 放射能の測定および $\boldsymbol{\gamma}$ 線スペクトロ メータによる核種分析

第 1. 節で述べたような方法で調製した武料の全 $\beta$ 放射能は GM 計数装置を用いて測定し， $\mathrm{U}_{3} \mathrm{O}_{8}$ の標準 試料( $\beta$ 線:500 d.p.s) と比較して放射能を計算した。試 料の探集時における放射能の算定については，平常時 の試料の場合，その減衰状態が Fig. 2 の(1)，(3)括よ び(4)に見られるように単調であり，また採集から最初 の測定までの時間が約 18〜20 hr で割合短時間である ことから，およそ $24 \mathrm{hr}$ をへだて 2 回目の測定を行 い，外括法によって操集時に打る放射能を逆算し た。一方, 爆発直後の試料の場合は, 試料によってそ の減衰状態が異るので, 最初の測定より 6〜10 hr お きに数回測定し，グラフ上に計数率をプロットして， 各測定值の標準偏差内に入るような曲線を引いて採集 時の值を外㨉によって求めた。一方，集塵器に装備さ れているヴィム型流量計によって測定した採取空気 体積を標準状態 $\left(760 \mathrm{mmHg}, 15^{\circ} \mathrm{C}\right)$ に換算して, $1 \mathrm{~m}^{3}$ あたりの放射能を計算した。さらにまた，Ge 半導体 検出器(東芝彆 $\mathrm{M}-8823$ 型 $\mathrm{Ge}(\mathrm{Li})$ Detector，検出有効 面直径：10 mm，検出有効厚 : $4 \mathrm{~mm}$, 分解能(半值幅) : $<7 \mathrm{keV}\left({ }^{137} \mathrm{Cs}\right.$ の662 keV ピークに扣いて))を用い た 線スペクトロメータで試料のスペクトルを一定時 間をへだてて测定を繰返しこれらの結果から含有核 種を推定した。

\section{3. 放射性塺の元素分析}

放射能測定が扣わった後の試料のうち，集塺器で採 取したものについて，採集回数 4 回分(平常時の試料は 約 1 力月間の 4 回分，核爆発直後の試料は25日〜27日 の間の 4回分)をまとめて 1 分析試料(約 $10 〜 20 \mathrm{mg}$ ) とし，Mattauch-Herzog 型 2 重収束質量分析器を用 いて成分元素の定量分析を行なった。

純度99. 999\%程度の純金の棒の先端に孔をあけ，こ れに 1 回 4 5 $\mathrm{mg}$ の試料をつめ( 1 試料について $3 \sim$ 4 回繰返して測定)，これを電極として真空中で高周 波火花放電を行わせて武料をイオン化し，発生したイ オンを 20〜30 kV で加速してエネルギー選択器学通 して後 $500 \mathrm{G}$ 程度の磁界に送り，分散させて写真乾板 上に焦点を結ばせてスぺクトルを求めた。エネルギー 選択器には $2,300 \mathrm{~V}$ の電圧をかけここでのイオン の偏向角は $31^{\circ} 48^{\prime}$ であり，磁界での偏向角は $90^{\circ}$ であ 
った。こうして得られたスペクトルについて、マイク ロフォトメータを用いて各スペクトル線の黒化度を測 定し，㐫らふじめ目的成分について作成した検量線に よりイオン強度を求めて定量した。また，集塵に使用 した沪紙と同種の未使用の沪紙20放を陚料と同様に処 理して分折し，沪紙 1 枚当りの含有元素量を算出して 試料の分析值から使用汇紙分の量を差し引いて厘自体 の組成元素量を求めた。

\section{III. 結果と考察}

Table 1は，1967年10月～1968年 4 月の期間に採集 した試料(いずれる集麼器使用)について得られた空中

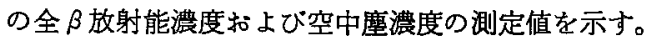
核爆発の約 1 力月前までの空中放射能浱度は $1 \mathrm{pCi} / \mathrm{m}^{3}$ 以下であっだが，25日11時頃に潮岬南東約 $120 \mathrm{~km}$ (N: $137^{\circ}, \mathrm{E}: 33^{\circ}$ 付近)の空域で採取したものは約 18,000 $\mathrm{pCi} / \mathrm{m}^{3}$ と非常に大きな值を示した。この試料の $\beta$ 放 射能の隇衰学調へた結果は Fig. 2 の曲線(2)に示すと 拉りであり, 平常時のものと比べて減衰が急激で, 新 しい核爆発生成物を含んでいたことは明らかである。 また27日以降の放射能濃度は低く，28日には $1 \mathrm{pCi} / \mathrm{m}^{3}$

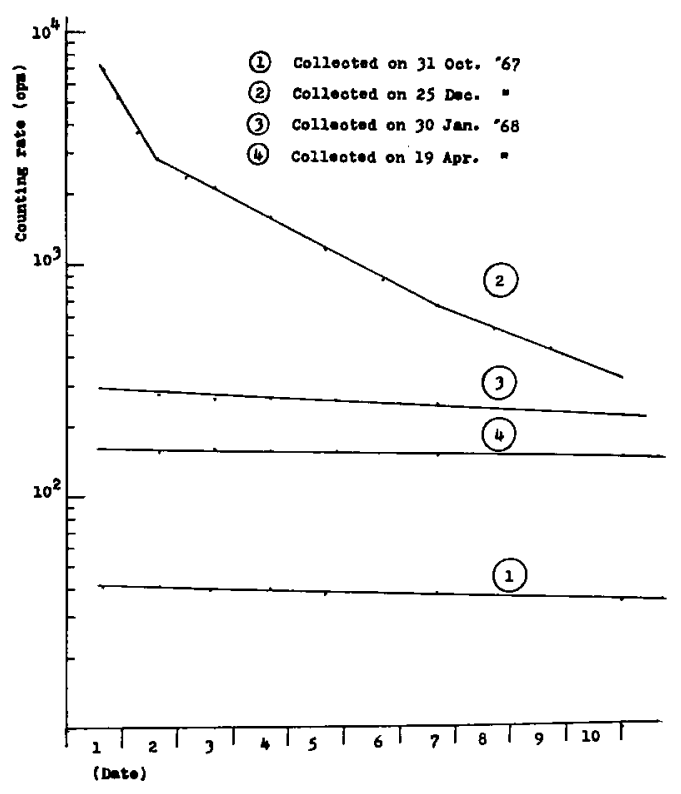

Fig. $2 \beta$-decay curves of radioactive airborne dusts

以下となっている。これは放射性塺を含んだ気団が

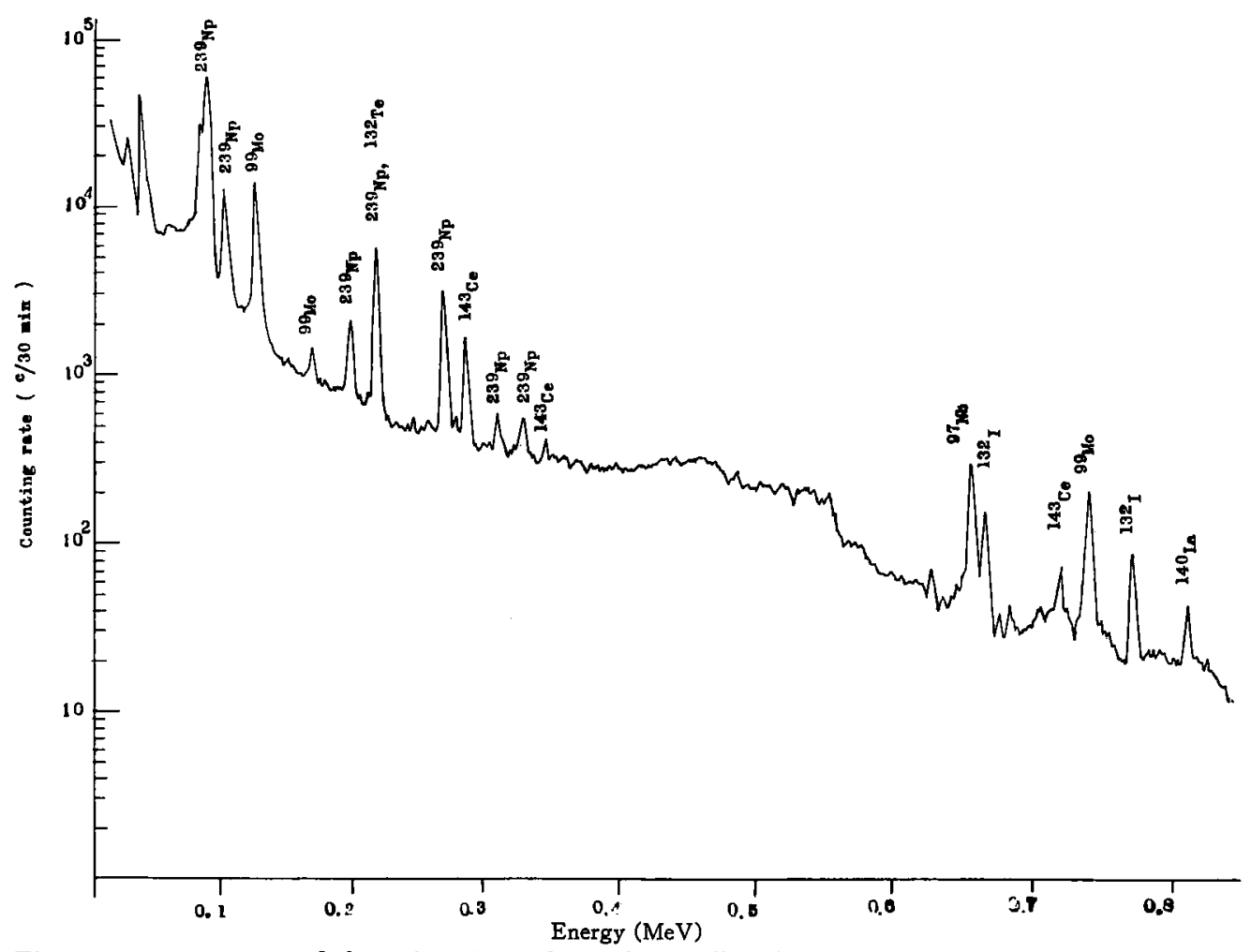

Fig. $3 \gamma$-ray spectrum of the radioactive airborne dusts collected on 25 Dec. '67, measured on 26 Dec. 
27日にはすでに通過し去ったことを示すすのと考えら

Table 1 Gross $\beta$-activity and concentration of airborne dusts in air at high altitude

\begin{tabular}{|c|c|c|c|c|}
\hline Date of sampling & & $\begin{array}{r}\text { Altitude } \\
(\mathrm{km})\end{array}$ & $\begin{array}{l}\text { Gross } \\
\beta \text {-activity } \\
\left(\mathrm{pCi} / \mathrm{m}^{3}\right)\end{array}$ & $\begin{array}{l}\text { Concen- } \\
\text { tration } \\
\text { of dust } \\
\left(\mu \mathrm{g} / \mathrm{m}^{8}\right)\end{array}$ \\
\hline 09.00 a.m., 11 Oct. & $' 67$ & 10 & 0.9 & 10.5 \\
\hline 01.00 p.m., $18 \quad " /$ & & 6 & 0.2 & 10.1 \\
\hline 09.00 a.m., $31 \quad / \prime$ & $\prime \prime$ & 10 & 0.4 & 9.3 \\
\hline 09.00 a.m., 24 Nov. & " & 6 & 0.2 & 11.5 \\
\hline 11.00 a.m., 25 Dec. & "l & 10 & 17,960 & 15.1 \\
\hline 09.00 a.m., 26 & $" \prime$ & 6 & 2,859 & 10.3 \\
\hline 01.00 p.m., 26 & $" 1$ & 6 & 203. 4 & 14.4 \\
\hline 09.00 a.m., 27 & $" 1$ & 6 & 2.8 & 12.7 \\
\hline 09.00 a.m., $28 \quad " \prime$ & $\prime \prime$ & 6 & 0.8 & 9.8 \\
\hline 10.00 a.m., 30 Jan. & '68 & 10 & 26.04 & 6.5 \\
\hline 10.00 a.m., $6 \mathrm{Feb}$. & $\prime \prime$ & 10 & 1.2 & 11.4 \\
\hline 10.00 a.m., $12 " /$ & "I & 10 & 18. 7 & 5.3 \\
\hline 09.00 a.m., $20 \quad / \prime$ & "l & 6 & 1.2 & 8.6 \\
\hline 09.00 a.m., 27 Mar. & $\prime \prime$ & 10 & 6.6 & 7.2 \\
\hline 09. 00 a.m., 1 Apr. & $\prime \prime$ & 6 & 0.5 & 7.4 \\
\hline 09.00 a.m., 19 "/ & $\prime \prime$ & 10 & 14.2 & 10.1 \\
\hline 09.00 a.m., 22 & 11 & 6 & 5.9 & 9.0 \\
\hline
\end{tabular}

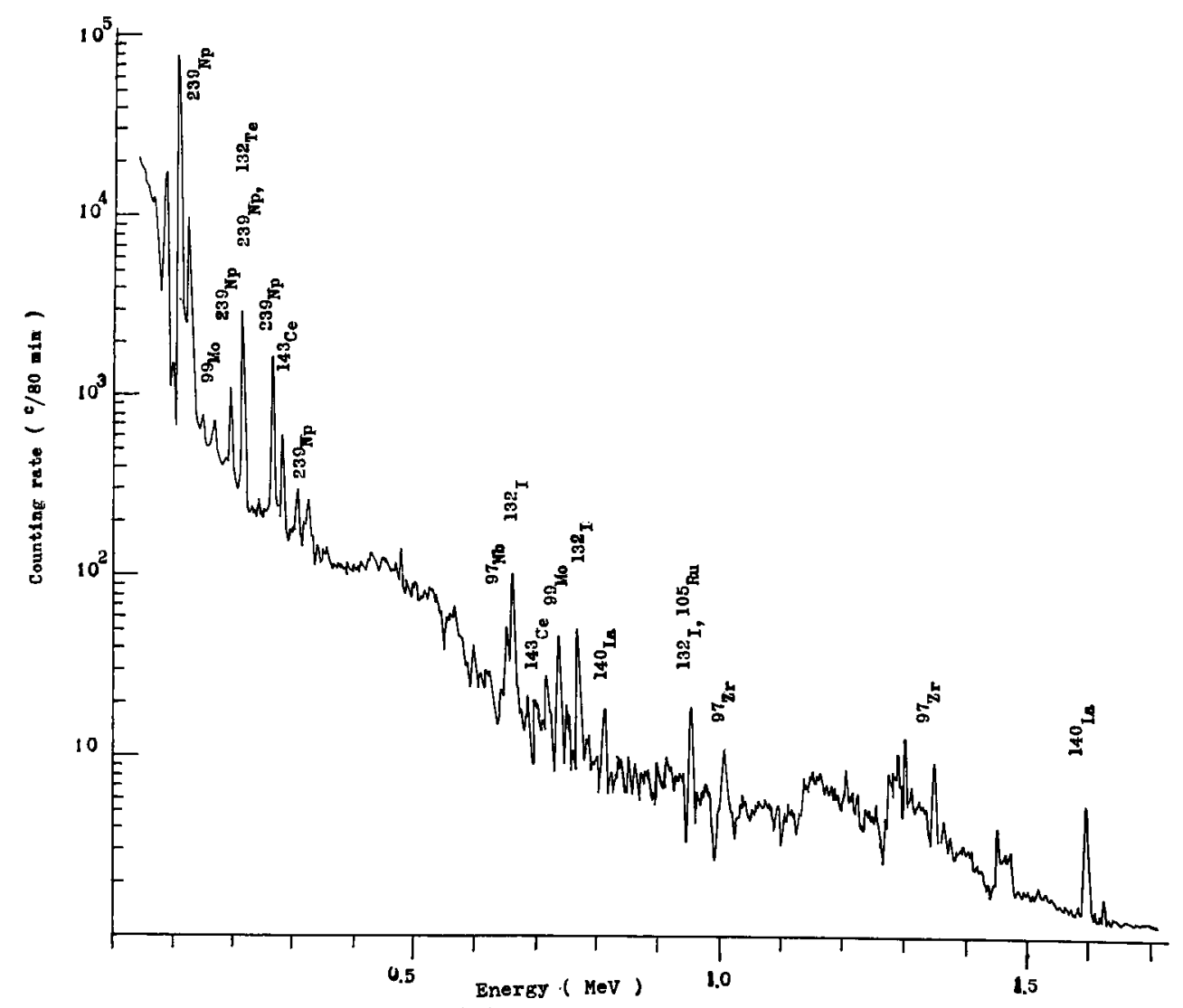

Fig. $4 \gamma$-ray spectrum of the radioactive airborne dusts measured on 28 Dec.
れる。また1967年12月末以降の湘定結果からは，核爆 発の影響が多少の消長を示しながら漸次らすれて行く ことが認められる。1月30日扰よび 2 月 12 日の試料が 比較的大をな值を示しているが，これは核爆発によっ て放出された放射性塵が拡散しながら地球の周りを何 回か移流したための影響によるすのと推定される。 た 4 月の值は他の平常時の值にくらべ全般的に幾分高 くなっている。これは，いままで報告されている測 定結果(5)等を考虑すると，今回の核爆発の影響に上る ばかりでなく，スプリングピーク(6)に大きく影響され たるのと考えられる。

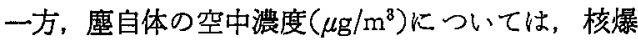
発直後に幾分增加したようにも思われるが，核爆発に 明らかに関連づけられるほどではない。また高度によ る変化についてす特に明白な傾向は出ていない。

Figs. 3，4は12月25日に探取した約 $18,000 \mathrm{pCi} / \mathrm{m}^{3}$ の $\beta$ 放射能を示した試料の $\gamma$ 線スペクトルである。

Fig. 3 は起爆 3 日後の12月26日午後测定した $1 \mathrm{MeV}$ 以下のェネルギーについてのスペクトルであり， Fig. 4 は28日に测定した $2 \mathrm{MeV}$ までのエネルギーについ 
てのスペクトルの例である。スペクトルに明瞭に現わ $0.278,0.228,{ }^{99} \mathrm{Mo}$ の $0.140,0.181,0.741,{ }^{143} \mathrm{Ce}$ の れているピークは, $1 \mathrm{MeV}$ 以下では ${ }^{289} \mathrm{~Np} の 0.106$, $0.294,0.722,{ }^{132} \mathrm{I} の 0.67,0.78 \mathrm{MeV}$ 等の各光電ピ

Table 2 Results obtained from quantitative analysis by mass spectrometry

\begin{tabular}{|c|c|c|c|c|c|c|}
\hline \multirow{2}{*}{$\begin{array}{l}\text { Atomic } \\
\text { No. }\end{array}$} & \multirow{2}{*}{ Element } & \multicolumn{2}{|c|}{ Sample No. 1} & \multicolumn{3}{|c|}{ Sample No. 2} \\
\hline & & $\begin{array}{c}\text { Component } \\
\left(W_{0}\right)\end{array}$ & $\begin{array}{l}\text { Concentration } \\
\text { in } \operatorname{air}\left(\mu \mathrm{g} / \mathrm{m}^{3}\right)\end{array}$ & $\begin{array}{c}\text { Component } \\
\left(W_{0}\right)\end{array}$ & $\begin{array}{l}\text { Abundance } \\
(\%)\end{array}$ & $\begin{array}{l}\text { Concentration } \\
\text { in } \operatorname{air}\left(\mu \mathrm{g} / \mathrm{m}^{3}\right)\end{array}$ \\
\hline $\begin{array}{r}3 \\
\\
4 \\
9 \\
11 \\
12 \\
13 \\
14 \\
15 \\
16 \\
17 \\
19 \\
20 \\
22 \\
23 \\
24 \\
25 \\
26 \\
27 \\
28 \\
29 \\
30 \\
32 \\
34 \\
35 \\
48 \\
50 \\
82\end{array}$ & $\begin{array}{ll}\mathrm{Li} & \\
& { }^{7} \mathrm{Li} \\
& \\
& \\
\mathrm{B} & \mathrm{Li} \\
\mathrm{F} & \mathrm{Na} \\
\mathrm{Na} & \\
\mathrm{Mg} \\
\mathrm{Al} \\
\mathrm{Si} \\
\mathrm{P} \\
\mathrm{S} \\
\mathrm{Cl} \\
\mathrm{K} \\
\mathrm{Ca} \\
\mathrm{Ti} \\
\mathrm{V} \\
\mathrm{Cr} \\
\mathrm{Mn} \\
\mathrm{Fe} \\
\mathrm{Co} \\
\mathrm{Ni} \\
\mathrm{Cu} \\
\mathrm{Zn} \\
\mathrm{Ge} \\
\mathrm{Se} \\
\mathrm{Br} \\
\mathrm{Cd} \\
\mathrm{Sn} \\
\mathrm{Pb} \\
\text { etc. } \\
\end{array}$ & $\begin{array}{c}0.04 \\
\\
0.59 \\
0.004 \\
9.51 \\
0.08 \\
0.04 \\
27.24 \\
0.05 \\
- \\
3.24 \\
31.91 \\
0.0006 \\
0.05 \\
0.04 \\
0.26 \\
0.007 \\
1.35 \\
0.04 \\
0.08 \\
0.46 \\
18.36 \\
0.003 \\
0.005 \\
0.001 \\
0.38 \\
0.11 \\
0.49 \\
5.65 \\
\end{array}$ & $\begin{array}{l}0.004 \\
\\
0.060 \\
0.0004 \\
0.977 \\
0.008 \\
0.004 \\
2.798 \\
0.005 \\
- \\
0.333 \\
3.277 \\
0.0001 \\
0.005 \\
0.004 \\
0.027 \\
0.0007 \\
0.139 \\
0.004 \\
0.008 \\
0.047 \\
1.886 \\
0.0003 \\
0.0006 \\
0.0001 \\
0.039 \\
0.011 \\
0.05 \\
0.582 \\
\end{array}$ & $\begin{array}{c}3.60 \\
(87.2) \\
(12.8) \\
0.04 \\
-\overline{1} \\
14.37 \\
0.03 \\
0.02 \\
42.12 \\
0.01 \\
3.07 \\
2.37 \\
8.48 \\
-\overline{-} \\
0.09 \\
-\overline{0} \\
0.004 \\
0.004 \\
0.42 \\
-\overline{10} \\
0.10 \\
0.13 \\
19.69 \\
0.02 \\
-- \\
-0 \\
0.03 \\
-\overline{0} \\
0.04 \\
5.36 \\
\end{array}$ & $\begin{array}{l}85.4 \\
14.6\end{array}$ & $\begin{array}{c}0.472 \\
(0.412) \\
(0.060) \\
0.005 \\
- \\
1.881 \\
0.003 \\
0.003 \\
5.514 \\
0.002 \\
0.402 \\
0.310 \\
1.111 \\
- \\
0.012 \\
- \\
0.0006 \\
0.0006 \\
0.054 \\
- \\
0.014 \\
0.016 \\
2.578 \\
0.003 \\
\overline{-} \\
\overline{0}-004 \\
\overline{-} \\
0.005 \\
0.699\end{array}$ \\
\hline & & \multicolumn{2}{|c|}{ Sample No. 3} & \multicolumn{3}{|c|}{ Sample No. 4} \\
\hline $\begin{array}{r}4 \\
9 \\
11 \\
12 \\
13 \\
14 \\
15 \\
16 \\
17 \\
19 \\
20 \\
22 \\
23 \\
24 \\
25 \\
26 \\
27 \\
28 \\
29 \\
30 \\
32 \\
34 \\
35 \\
48 \\
50 \\
82\end{array}$ & $\begin{array}{l}{ }^{\mathrm{Li}}{ }^{7} \mathrm{Li} \\
{ }^{6} \mathrm{Li} \\
\mathrm{B} \\
\mathrm{F} \\
\mathrm{Na} \\
\mathrm{Mg} \\
\mathrm{Al} \\
\mathrm{Si} \\
\mathrm{P} \\
\mathrm{S} \\
\mathrm{Cl} \\
\mathrm{K} \\
\mathrm{Ca} \\
\mathrm{Ti} \\
\mathrm{V} \\
\mathrm{Cr} \\
\mathrm{Mn} \\
\mathrm{Fe} \\
\mathrm{Co} \\
\mathrm{Ni} \\
\mathrm{Cd} \\
\mathrm{Zn} \\
\mathrm{Ge} \\
\mathrm{Se} \\
\mathrm{Br} \\
\mathrm{Cd} \\
\mathrm{Sn} \\
\mathrm{Pb} \\
\text { etc. } \\
\end{array}$ & $\begin{array}{c}0.26 \\
\\
1.29 \\
0.01 \\
3.96 \\
0.13 \\
0.06 \\
60 \\
0.09 \\
0.31 \\
0.55 \\
12.66 \\
- \\
0.06 \\
0.03 \\
0.02 \\
- \\
0.07 \\
0.07 \\
-\overline{16} \\
0.16 \\
11.02 \\
0.01 \\
0.003 \\
0.003 \\
0.32 \\
-\overline{10} \\
0.81 \\
\end{array}$ & $\begin{array}{l}0.021 \\
\\
0.102 \\
0.001 \\
0.315 \\
0.010 \\
0.004 \\
4.767 \\
0.008 \\
0.025 \\
0.043 \\
1.006 \\
- \\
0.005 \\
0.002 \\
0.002 \\
-\overline{0} \\
0.005 \\
0.005 \\
- \\
0.013 \\
0.876 \\
0.0008 \\
0.0002 \\
0.0003 \\
0.026 \\
-\overline{0} \\
0.008 \\
0.70 \\
\end{array}$ & $\begin{array}{c}1.49 \\
(90.8) \\
(9.2) \\
0.10 \\
0.002 \\
14.94 \\
0.45 \\
0.39 \\
48.77 \\
0.22 \\
20 \\
0.22 \\
9.29 \\
0.003 \\
0.13 \\
0.04 \\
0.06 \\
0.02 \\
1.12 \\
- \\
0.004 \\
0.16 \\
1.32 \\
0.002 \\
- \\
- \\
- \\
- \\
0.02 \\
1.24 \\
\end{array}$ & $\begin{array}{l}89.4 \\
10.6\end{array}$ & $\begin{array}{l}0.125 \\
(0.113) \\
(0.012) \\
0.009 \\
0.0002 \\
1.257 \\
0.038 \\
0.034 \\
4.104 \\
0.019 \\
1.683 \\
0.018 \\
0.782 \\
0.0003 \\
0.011 \\
0.004 \\
0.005 \\
0.001 \\
0.094 \\
- \\
0.0004 \\
0.013 \\
0.111 \\
0.0002 \\
- \\
- \\
- \\
- \\
0.002 \\
0.105 \\
\end{array}$ \\
\hline
\end{tabular}

* Sample No. 1: Collected 11, 18, 31 Oct. and 24 Nov. No. 2: Collected 25, 26, 27 Dec. 
ークまた $1 \mathrm{MeV}$ 以上では ${ }^{97} \mathrm{Zr}$ の1.02および ${ }^{140} \mathrm{La}$ の $1.6 \mathrm{MeV}$ の光電ピークであるが, これらの 5 ら ${ }^{239} \mathrm{~Np}$ のピークがもっとも優勢でめる。

${ }^{238} \mathrm{U}$ をタンパーとして使用した揚合の核爆発反応 によって生ずる ${ }^{237} U$ の放射性降下物中からの検出に ついては，すでにいくつかの報告(7) ( (9) がある。本試 料については， $\gamma$ 線スペクトロメトリーからは確認す ることができなかった。したがって，むし存在すると してもその量はきわめて少ないものと思われる。

Table 2 は, 探集浮遊糜の組成成分の質量分析器 による分析結果を示す。各試料とる約 20 余種の元素が 検出されたが，そのうら Si, Na 战よびKの含有量が 大きく全体の約70\%をしめている。これら検出された 組成成分を理科年表等に示されている土㙥母材として の火成岩や堆積岩の平均化学組成と比較すると， $\mathrm{Na}$ およびKの含有量が大きいのに反して， Al, Fe 怙よび $\mathrm{Ca}$ 等が非常に小さくなっている。一方，フォールア ウト粒子の組成成分については，真室らによって報告 (10) (12)されているよ5に， $\mathrm{Fe}, \mathrm{Ca}, \mathrm{Si}$ 扎よび $\mathrm{Al}$ 等数 種の元素が主体をなし，一般的には Fe が多いといわ れている。なお，これら元素の成分比は，その粒子の 生成条件によって広い籍囲に異なるといわれている。 $\mathrm{Si}, \mathrm{Na}$ およ゙Kの含有量が大きいという本分析結果 は, 浮遊塵の主要構成物質が単に土坮物質に由来する るののみでないことを示していると考えられる。む た，核爆発直後の試料についてもほほ同様な分析結果 が得られたことは，その主要棈成物質もフォールフウ 卜粒子ではなかったことを示している。いずれにして る，本分析結果については目下のところまだ満足な説 明が与えられない。

Table 2 k見られるように，一般的にいって塵の主 要成分については，核爆発直後怙よび平常時の相異は 特に見られない。しかし Li 元素の空中襄度について は，嚗発直後のものがその前後に比へて明らかに高 い。すなわち，核爆発の約 1 力月前の試料の約 120 倍, 爆発後の 2 月試料の約23倍となっている。また 4 月試 料は 2 月試料上りは増加しているが，核爆発直後の武 料の1/4の值を示すにすぎない。したがって，この結果 から見ると，核爆発によって Li元素が大気中に放出さ れ，その後拡散移流の結果空中濃度は減少して行き， 4月にはスブリングピークによる過去の塵の影響が加 わって含有量が増加したすのと考光られる。なお， Li
元素の質最数 6 と 7 の存在比を見ると, 核爆発直後の 武料では， ${ }^{6} \mathrm{Li}$ が天然のものの場合に比べて約 2 倍の $14.6 \%$ を示している。爆発前後の10月括よび2月の試 料については存在比を精確に測定することができなか ったが，4月試料では10.6\%とい5測定值が得られ， これは天然の存在比に比べてI.4倍となっている。こ の上5な爆発直後に扎ける $\mathrm{Li}$ 濃度増加括よび ${ }^{6} \mathrm{Li} の$ 存在比の增加のすべてが爆弾から放出された Li によ るものであるとすることはできないとしても，核爆発 に強く関連していると結論することは妥当と考える。 またU元素についても検出をはかったが，いずれの試 料からあ確認することはできなかった。

以上の結果を総合すると，核爆発直後に括ける放射 能に関しては，その空中濃度が急激に増大し，新しい 核爆発生成物の存在が明瞭に確諗でき，また含有核種 についても推定できた。一方， ${ }^{237} U$ は検出できず， したがって熱核反応は起こらなかったと推定される が，核爆発直後において Li 元素の空中含有量が堌加 したこと，および質量数 6 の存在比が天然のものの場 合の約 2 倍であったことは，この核爆発実験に如いて 放出された濃縮 ${ }^{6} \mathrm{Li}$ に起因するるのと考えられる。

本研究の実施に当って質量分析および核種分析につ いてご援助，ご協力下さった東芝中央研究所の寺田実 男博士はじめ近藤正之氏，高柳誠一氏，梅宫伸夫氏に深 く感謝いたします。

\section{一一参考文 献—}

（1）木村健二郎：分析化学, 3[4], 335(1954).

(2) Mamuro, T., Matsunami, T.: Nature, 218 [5141], 555 556 (1968).

(3) 気象協会：地球物理学文献抄，10, 407 451(1963)-

(4) URAI, T.: J. Nucl. Sci. Technol., 2 [1], 18 (1964).

(5) URAI, T.: 本 誌, 5[9], 735 (1963).

(6) 三宅泰雄 : 科 学, 34[3]. 143(1964).

(7) 真室折雄, 他 : 本 誌, 8[5], 242 248 (1966).

（8）三宅泰雄，他：故射線影響学会第 7 回研究発表会, (1965).

（9）小山誠太郎, 他：同上第 8 回研究発表会, (1966).

(11) 真室哲雄, 他：本 誌, 5[6], 491 497 (1963).

(11) 真室哲雄, 他: 同 上, 8 [6], 309 316 (1966).

(12) Кеммосні, M.: J. Nucl. Sci. Technol., 3[3], 106 113 (1966). 